\title{
Guillain-Barre Syndrome Following a Snakebite: A Case Report and Review of Literature
}

\author{
Sajid Hameed ${ }^{1}$, Mubashar Memon ${ }^{1}$, Sara Khan ${ }^{1}$ \\ 1. Neurology, Aga Khan University, Karachi, PAK
}

Corresponding author: Sajid Hameed, sajid.hameed@aku.edu

\begin{abstract}
Guillain-Barre syndrome (GBS) is preceded by a respiratory or gastrointestinal illness in more than $50 \%$ of the patients. A rare association of GBS with a preceding snakebite is reported in the literature in only four previous cases. We present a case report of a patient diagnosed with GBS following the bite of a yellowbellied sea snake (Hydrophis platurus) and a brief review of the available literature.
\end{abstract}

Categories: Neurology

Keywords: snake bite, guillain-barre syndrome

\section{Introduction}

Guillain-Barre syndrome (GBS) is an acute-onset acquired polyneuropathy with an annual incidence of 0.5-2 cases per 100,000 [1]. More than half of the patients have a history of preceding respiratory or gastrointestinal illness. An association of GBS with preceding snakebite is rare and has been reported in the literature in only four previous cases. We present a case of GBS following snakebite and a brief review of the available literature.

\section{Case Presentation}

A 21-year-old male, fisherman by profession, presented with a three-week history of progressive generalized weakness, diplopia, decreased appetite and lethargy with difficulty in performing activities of his daily living. For the past three days, he was having a high-grade fever and shortness of breath. He was managed in the medicine department with the diagnosis of aspiration pneumonia with type- 1 respiratory failure. The patient reported that six weeks ago, he was bitten by a yellow-bellied sea snake (Hydrophis platurus) on his left palm during fishing. No anti-venom was administered at that time. Neurology team was consulted on the second day of admission.

Received 07/19/2019

Review began 07/23/2019 Review ended 07/24/2019 Published 07/30/2019

(c) Copyright 2019 Hameed et al. This is an open access article distributed under the terms of the Creative Commons Attribution License CC-BY 3.0., which permits unrestricted use, distribution, and reproduction in any medium, provided the original author and source are credited.
On physical examination, he had a blood pressure of $90 / 60 \mathrm{mmHg}$, a pulse of 85 per minute and a temperature of 98.2 F. He was on continuous non-invasive ventilation (NIV) support for his hypoxia. He had a well-demarcated clean healing wound of around 2-cm in diameter on his left palm. He was awake and oriented with intact higher mental functions. Pupils were of 3-mm bilaterally and reactive to light and accommodation. Right lateral rectus palsy was noted. There was no facial muscle weakness and tongue was central on protrusion. His speech had a hyper-nasal quality. Movements of soft palate and uvula were absent on testing with an absent gag reflex. On motor examination, he had normal bulk without fasciculation. Muscle tone was mildly reduced in all limbs. In both upper limbs, he had muscle strength of Medical Research Council (MRC) grade 3/5 in proximal muscle groups and MRC grade 4/5 in distal muscle groups, while in lower limbs he had MRC grade of $4 / 5$ in both proximal and distal muscle groups. Deep tendon reflexes were absent in all four limbs. Sensory examination was unremarkable.

\section{Investigations}

Initial laboratory investigations (on day one) are shown in Table 1. 


\section{Cureus}

\begin{tabular}{|c|c|c|}
\hline Test & Result & Reference \\
\hline Hemoglobin & $15.6 \mathrm{~g} / \mathrm{dL}$ & $12.3-16.6 \mathrm{~g} / \mathrm{dL}$ \\
\hline White blood cell count & $18.2 \times 10 \mathrm{E} 9 / \mathrm{L}$ & $4.8-11.3 \times 10 \mathrm{E} 9 / \mathrm{L}$ \\
\hline Neutrophils & $85.8 \%$ & $34.9-76.2 \%$ \\
\hline Lymphocytes & $4.4 \%$ & $17.5-45 \%$ \\
\hline Platelet count & $544 \times 10 \mathrm{E} 9 / \mathrm{L}$ & $154-433$ x 10E9/L \\
\hline Procalcitonin & $1.67 \mathrm{ng} / \mathrm{mL}$ & Positive > $2.0 \mathrm{ng} / \mathrm{mL}$ \\
\hline Magnesium & $1.8 \mathrm{mg} / \mathrm{dL}$ & $1.6-2.6 \mathrm{mg} / \mathrm{dL}$ \\
\hline Blood urea nitrogen & $32 \mathrm{mg} / \mathrm{dL}$ & $6-20 \mathrm{mg} / \mathrm{dL}$ \\
\hline Creatinine & $1.3 \mathrm{mg} / \mathrm{dL}$ & $0.9-1.3 \mathrm{mg} / \mathrm{dL}$ \\
\hline Sodium & $140 \mathrm{mmol} / \mathrm{L}$ & $136-145 \mathrm{mmol} / \mathrm{L}$ \\
\hline Potassium & $3.8 \mathrm{mmol} / \mathrm{L}$ & $3.5-5.1 \mathrm{mmol} / \mathrm{L}$ \\
\hline Chioride & $97 \mathrm{mmol} / \mathrm{L}$ & $98-107 \mathrm{mmol} / \mathrm{L}$ \\
\hline Bicarbonate & $33.1 \mathrm{mmol} / \mathrm{L}$ & $20-31 \mathrm{mmol} / \mathrm{L}$ \\
\hline Calcium & $9.6 \mathrm{mg} / \mathrm{dL}$ & $8.6-10.2 \mathrm{mg} / \mathrm{dL}$ \\
\hline Erythrocyte sedimentation rate & $95 \mathrm{~mm} / 1 \mathrm{st}$ hour & $0-15 \mathrm{~mm} / 1 \mathrm{st}$ hour \\
\hline C-reactive protein & $15.59 \mathrm{mg} / \mathrm{dL}$ & $0-0.5 \mathrm{mg} / \mathrm{dL}$ \\
\hline
\end{tabular}

TABLE 1: Laboratory investigations

Our differential diagnosis indicated either a brainstem stroke or demyelination. Cranial magnetic resonance imaging (MRI) was negative for an acute brainstem stroke or abnormal contrast enhancement (Figure 1). 


\section{Cureus}

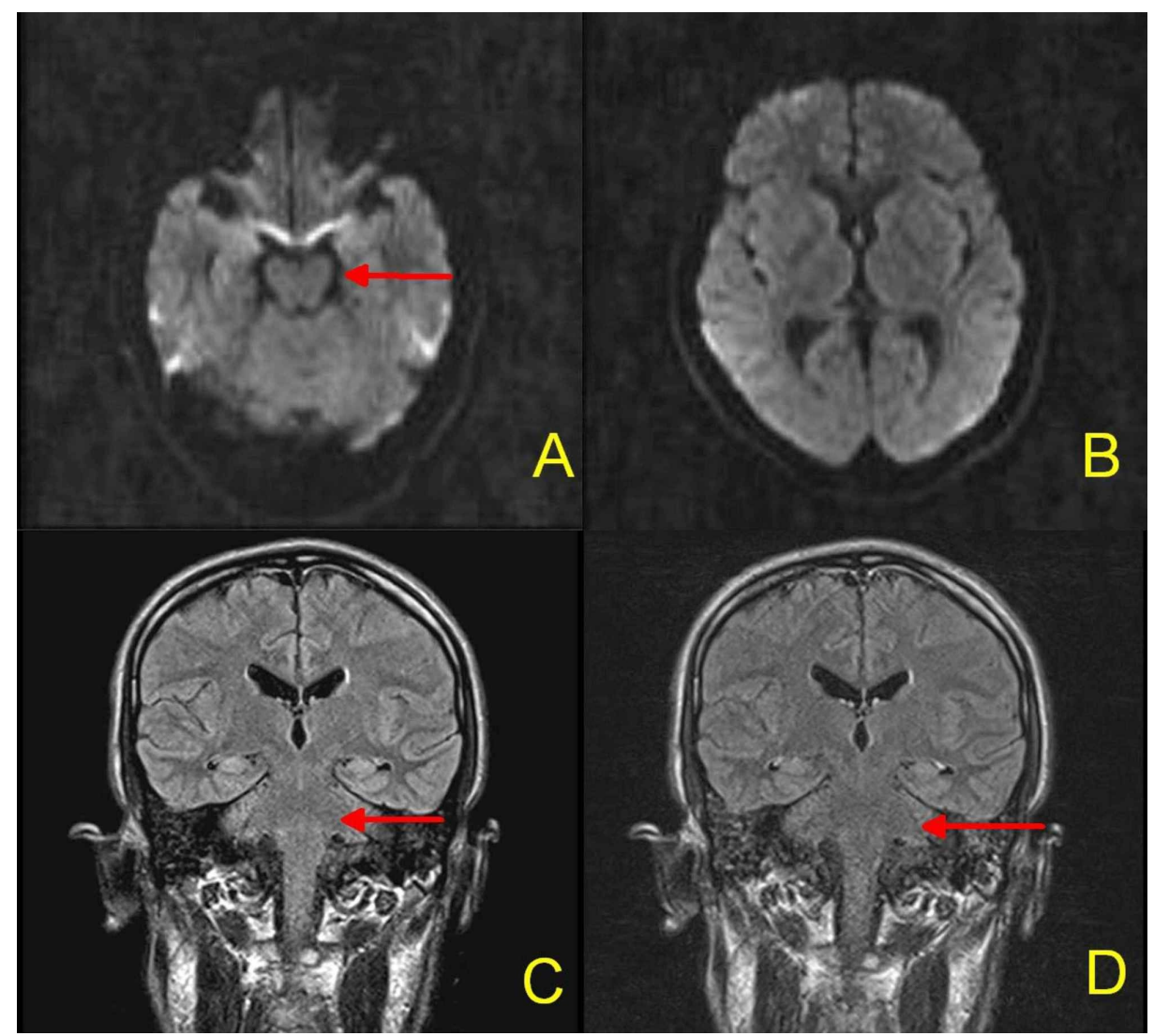

FIGURE 1: MRI Brain: No acute ischemic stroke on DWI sequences (Figure 1A, 1B). No abnormal signals on pre-contrast ( Figure 1C) or post-contrast FLAIR sequence (Figure 1D). Red arrows indicate brainstem, which is normal

MRI = Magnetic resonance imaging; DWI = Diffusion-weighted imaging; FLAIR = Fluid-attenuated inversion recovery

On the third day of admission, electromyography and nerve conduction studies (EMG/NCS) were performed. These revealed normal sensory nerve conduction, while motor amplitudes of the bilateral peroneal, right median, and ulnar nerves were reduced without a conduction block. In the clinical context, the patient was diagnosed with an acute motor axonal neuropathy (AMAN) variant of GBS.

\section{Management}

The patient was initially managed with continuous NIV and broad-spectrum antibiotics for aspiration pneumonia.

On the third day of admission, plasmapheresis was initiated after obtaining the EMG/NCS results. The decision of plasmapheresis over IVIG was made based on the patient's preference. Vital capacity was monitored regularly. After the third session of plasmapheresis (on day five), he developed severe respiratory distress and $\mathrm{SaO} 2$ dropped to $65 \%$ despite NIV following which he was intubated. The remaining two sessions of plasmapheresis were done in the intensive-care unit (ICU). On the seventh day of admission, the final (fifth) session of plasmapheresis was done. On day nine, the patient was extubated.

From days 9-14, the patient underwent regular inpatient physiotherapy and rehabilitation. On day 14, he was discharged home in a stable condition with a nasogastric tube (NGT) in place.

\section{Follow-up}

The patient was stable on the first follow up at the clinic (after three weeks of being discharged from the hospital). The NGT was removed and he was taking food orally. Muscle strength was of MRC grade $3 / 5$ in all four limbs. Right lateral rectus palsy was present.

On the second clinic follow up (after four months of being discharged from the hospital), the patient 
regained his muscle strength to MRC grade $5 / 5$ in all four limbs and was ambulating without difficulty. The right lateral palsy persisted.

\section{Discussion}

Guillain-Barre syndrome is an acute autoimmune-mediated polyneuropathy that commonly presents with bilateral symmetrical ascending flaccid paralysis. However, variations in the clinical presentation of GBS do exist, as in our case. About 70\% of patients with GBS have a preceding event, most commonly a respiratory or gastrointestinal illness. Additionally, GBS is reported to be associated with surgery, cancer, and vaccines [1]. Only a few case reports suggest an association of a snakebite with GBS [2-4].

In 1996, Chuang et al. reported the first case of GBS in association with a snakebite [2]. The patient presented with progressive quadriparesis, autonomic dysfunction, and cerebrospinal fluid (CSF) cytoalbuminologic dissociation, four weeks after the bite of a Formosan krait (Bungarus multicinctus). EMG/NCS revealed sensorimotor axonal-type polyneuropathy. The patient improved with subsequent treatment (plasmapheresis and methylprednisolone of $500 \mathrm{mg} /$ day for five days) and rehabilitation.

The second case was reported by Srivastava et al. in 2010 [3]. In this case, the patient presented with bilateral paresthesia in the upper limbs and quadriparesis five weeks after the snakebite. The snake species could not be identified. EMG/NCS revealed motor and sensory neuropathy-primarily suggestive of demyelination with secondary axonal degeneration. The patient improved with plasmapheresis.

In 2011, Neil et al. [4] reported the third case of GBS following the bite of the snake, Vipera aspis. The patient presented with paraesthesia and quadriparesis after 12 days of snakebite. The authors went one step further and demonstrated cross-reactivity between venom proteins and neuronal GM2 gangliosides (molecular mimicry), postulating a potential immunological basis for this association rather than direct venom toxicity.

The fourth case was reported in 2014 by Neto et al. from Brazil [5]. In this case, the patient presented with quadriparesis and areflexia following the bite of Rattlesnake (Crotalus sp.) two weeks back. The patient improved with intravenous immunoglobulin (IVIG) and rehabilitation. EMG/NCS performed on follow-up (on the 60th day) was consistent with sensory and motor axonal polyradiculoneuropathy.

To the best of our knowledge, this is the fifth case of GBS associated with a snakebite. All the patients presented later, from 12 days [5] to five weeks [3], following the snake bite indicating an immune-related etiology rather than direct effects of the toxin, as suggested by Neil et al. [4]. Another possibility was that the anti-venom may be associated with GBS rather than the snake venom itself. However, two of the patients, including ours, didn't receive the anti-venom [4]. All the patients improved with treatment and were able to perform activities of daily living on follow-up visits. One patient received IVIG and three patients received plasmapheresis, out of which one also received additional methylprednisolone. The treatment of the remaining patient is unknown. Both IVIG and plasmapheresis are equally effective in the treatment of GBS, while steroids have no proven role [1].

Our case was slightly different in that the snake was native to water and the polyneuropathy was of pure motor type (AMAN variant of GBS), while all other cases presented with mixed sensorimotor polyneuropathies. All the previous case reports have been summarized in Table 2. 


\section{Cureus}

\begin{tabular}{|c|c|c|c|c|c|c|}
\hline $\begin{array}{l}\text { Authors } \\
\text { (Country \& } \\
\text { year) }\end{array}$ & $\begin{array}{l}\text { Snake } \\
\text { species }\end{array}$ & Clinical features & $\begin{array}{l}\text { Time duration } \\
\text { from snakebite to } \\
\text { Presentation }\end{array}$ & $\begin{array}{l}\text { Antivenom } \\
\text { received }\end{array}$ & EMG/NCS & Treatment \\
\hline $\begin{array}{l}\text { Chuang et } \\
\text { al. [2] } \\
\text { (Taiwan, } \\
\text { 1996) }\end{array}$ & $\begin{array}{l}\text { Formosan } \\
\text { krait } \\
\text { (Bungarus } \\
\text { multicinctus) }\end{array}$ & $\begin{array}{l}\text { Quadriparesis, facial } \\
\text { weakness, and } \\
\text { autonomic dysfunction }\end{array}$ & Four weeks & Yes & $\begin{array}{l}\text { Sensorimotor axonal-type } \\
\text { polyneuropathy. }\end{array}$ & $\begin{array}{l}\text { Plasmapheresis; } \\
\text { Methylprednisolone, } \\
500 \mathrm{mg} / \mathrm{d} \text { for five days }\end{array}$ \\
\hline $\begin{array}{l}\text { Srivastava } \\
\text { et al. [3] } \\
\text { (India, 2010) }\end{array}$ & --- & $\begin{array}{l}\text { Quadriparesis and } \\
\text { paresthesia in upper } \\
\text { limbs. }\end{array}$ & Five weeks & Yes & $\begin{array}{l}\text { Sensorimotor polyneuropathy- } \\
\text { primarily suggestive of demyelination } \\
\text { with secondary axonal degeneration. }\end{array}$ & Plasmapheresis \\
\hline $\begin{array}{l}\text { Neil et al. } \\
{[4] \text { (France, }} \\
\text { 2011) }\end{array}$ & $\begin{array}{l}\text { Viper (Vipera } \\
\text { Aspis) }\end{array}$ & $\begin{array}{l}\text { Paresthesia in all four } \\
\text { extremities, gait ataxia, } \\
\text { and quadriparesis }\end{array}$ & 12 days & No & $\begin{array}{l}\text { Sensorimotor polyneuropathy - } \\
\text { primarily suggestive of demyelination } \\
\text { with conduction block }\end{array}$ & 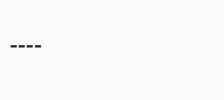 \\
\hline $\begin{array}{l}\text { Neto et al. } \\
\text { [5] (Brazil, } \\
\text { 2014) }\end{array}$ & $\begin{array}{l}\text { Rattlesnake } \\
\text { (Crotalus sp.) }\end{array}$ & Quadriparesis & Two weeks & Yes & $\begin{array}{l}\text { Sensorimotor axonal } \\
\text { polyradiculoneuropathy. }\end{array}$ & IVIG \\
\hline
\end{tabular}

TABLE 2: Case reports of Guillain-Barre syndrome following snake bite.

EMG/NCS = Electromyography and nerve conduction studies; IVIG = intravenous immune globulin

Snakebite is a common condition, but a neglected one [6]. Although exact data is lacking, the annual estimates vary from 4.5 to 5.4 million snakebites, 1.8 to 2.7 million envenomings, and 81,000 to 138,000 deaths according to the World Health Organization [7]. Despite these huge numbers, only a handful of cases of GBS following snakebite are reported in the literature. We can assume that many cases would have been missed due to under-reporting. Nonetheless, further studies are needed to confirm the association between GBS following a snakebite.

\section{Conclusions}

The temporal association of the snakebite with GBS in all the aforementioned cases suggest a possible association. Patients with a snakebite should be observed for new-onset flaccid weakness for multiple weeks and if present, it should be addressed urgently. The prognosis is excellent if timely interventions are performed.

\section{Additional Information \\ Disclosures}

Human subjects: Consent was obtained by all participants in this study. Conflicts of interest: In compliance with the ICMJE uniform disclosure form, all authors declare the following: Payment/services info: All authors have declared that no financial support was received from any organization for the submitted work. Financial relationships: All authors have declared that they have no financial relationships at present or within the previous three years with any organizations that might have an interest in the submitted work. Other relationships: All authors have declared that there are no other relationships or activities that could appear to have influenced the submitted work.

\section{References}

1. Donofrio PD: Guillain-Barré syndrome. Continuum (Minneap Minn). 2017, 23:1295-309. 10.1212/CON.0000000000000513

2. Chuang TY, Lin SW, Chan RC: Guillain-Barre syndrome: an unusual complication after snake bite . Arch Phys Med Rehabil. 1996, 77:729-31.

3. Srivastava A, Taly AB, Gupta A, Moin A, Murali T: Guillain-Barre syndrome following snake bite: An unusual complication. Ann Indian Acad Neurol. 2010, 13:67. 10.4103/0972-2327.61284

4. Neil J, Choumet V, Le Coupanec A, d'Alayer J, Demeret S, Musset L: Guillain-Barre syndrome: First description of a snake envenomation aetiology. J Neuroimmunol. 2012, 18:72-7. 10.1016/j.jneuroim.2011.11.007

5. Neto EGC, Macedo MJA, Silva FV, Foseca AJ, Fonseca ARR: Guillain-Barré syndrome after a snakebite: case report and literature review. Revista brasileira de neurologia e psiquiatria. 2014, 18:253-7.

6. Chippaux JP: Snakebite envenomation turns again into a neglected tropical disease! . J Venom Anim Toxins Incl Trop Dis. 2017, 23:38. 10.1186/s40409-017-0127-6 


\section{Cureus}

7. Prevalence of snakebite envenoming. (2019). Accessed: July 14, 2019: https://www.who.int/snakebites/epidemiology/en/. 